\title{
Job Localization Policy in Saudi Arabia: Determining its Effect on Employment and Economy
}

\author{
Saad Mohammed Othman \\ Department of Finance and Economics, University of Sharjah \\ P. O. Box 27272, University City Road, Sharjah, United Arab Emirates \\ Tel: 971-6-5585000Ｅ-mail: sjaibeji@sharjah.ac.ae
}

Received: Dec. 28, 2016 Accepted: Jan. 9, 2017 Published: Feb. 3, 2017

doi:10.5296/bmh.v5i1.10681～URL: http://dx.doi.org/10.5296/bmh.v5i1.10681

\begin{abstract}
Saudi Arabia as part of the largest peninsula in the world is confronting with the incongruity of expanding adolescent unemployed nationals and its egotistical dependence on global business and employment for private organizations. In this topic, Saudi legislature has made assorted strategies to battle unemployment of nationals through job localization policy commonly known as "Saudization". The goals of the discernible administrative arrangement are to lessen the aplenty of global workers through distinguishable standard targets and force confinements on the enlistment procedure of global workers. Abundant research, investigations and reports have uncovered that the precedent-setting stage might realize a spate of instigations for private organizations in the job from claiming Saudi nationals. In any case, the placidity owning of private organizations is take unreservedly to job applications who are global workers prepared to embrace physically difficult works to meet the expectations of organizations with lower compensation. This paper investigates the presumptions behind this acceptance, in an application to be aware better the burly ramifications of job localization policy to global workers and fundamentally evaluate the most qualified fresh saudization proposal pegged as "nitaqat" in the implementation procedure of the national manpower in Saudi Arabia.
\end{abstract}

Keywords: Global workers, Job localization policy, Nitaqat, Saudization, Saudi Arabia

\section{Introduction}

Saudi Arabia is probably the wealthiest nations in the Middle East and top world natural gas supplier and maker. The state's incomes from oil exports have given the foundation to the fast-track advancement of economy. This rapid economic growth and increasing populace made similarly surge in person's profession. In this manner, the kingdom confronts an 
aggressive habituated of oppressions that include knowledge learning and competence with a specific end goal to meet the necessities of development and advancement (Elhadj, 2010). Hammer et al. (2004) affirmed that the deficiency of educated innate specialists forced organizations to supply comprehensive employment opportunities to skilled global workers from seventy nations around the globe. This legitimate information is parallel with the recent report of government bureau's world fact book that the global workers in the kingdom are assessed to number nine million or roughly thirty-one percent yet the developing volume of talented Saudis both genders to work in action is problematic to get a job (CIA, 2009). According to the report of International Monetary Fund (IMF), the figure of jobless Saudi nationals ballooned to 11.6 percent and it has reached 32.8 percent among women (Al-Barjas, 2016). Albeit both are showing superior and employable, the concentrations in any case, demonstrate that diverse organizations are blatantly dependent on global workers to the degree that international occupants establish almost thirty-three percent of the aggregate populace (Alanezi, 2012; Sadi, 2013).

Regardless of those exceptional political and financial securities, the Saudi government has an issue of delivering employment to its nationals. Normally, the focus will be the global workers who were recognized on bringing out those employments of Saudi national. For this situation, the Saudi Ministry of Labor endorsed the Ministerial Resolution No. 4040 dated 12/10/1432 Hijdi calendar in relating to 10/09/2011 and declared another approach activity known as job localization policy or the so-called the Saudization. According to the study by Randeree (2009) their work localization endeavors are the expressed objectives and verbalized strategies of the nation as another stage from claiming its advancement. Empirical studies indicate that this strategy with ambitious targets might have been outlined to diminish the broad dependence on global workers by empowering, regularly convincing, private commercial enterprises to employ nationals rather than global workers and eradicate conceivable distress from the white-collar class (Randeree, 2012).

Practices and policies such as the saudization arrangement are not unknown events and have been portrayed similarly as job localization policy over the concurrent broad management and marketing reports (Koyame-Marsh, 2016; De Bel-Air, 2015; Al-Asfour \& Khan, 2014). Various researchers like Altamimi (2014) revealed that this arrangement may be introduced to different investigations of the socialization and cultural procedures that influences global workers and locals in the working environment. Its viability need gained extensive interest, the measure about exploration are blended with some being carefully optimistic, while others feel that demographic adversities will be a reason in long-term issues if work generation is not made right away (Hertog, 2012; Al-Dosary \& Nahiduzzaman, 2010). This likewise pushed eventually by diverse academic scholars and experts who draw special attention to the security ramifications of demographic adversities (Coates-Ulrichsen, 2011; Winckler, 2010; Spiess, 2010).

In government points of view, in spite of the fact that the position of skilled Saudi nationals and global workers have been perceived and acknowledge in pursuit of reliable standard labor import policies and pecuniary development of the kingdom, the literatures at any rate, show that private organizations retaliated promptly to recruit global workers that are 
committed and adaptable to expand organizational profitability and benefits (Torofdar, 2011). This is predominantly because of compensations, interpersonal work behavioral reasons, training and development skills, and organizational leadership. Moreover, the reasons of huge number of global workers in private sector is because of the difficulties associated with the success of localization in the kingdom as such: (i) labor cost; (ii) social and cultural perceptions; (iii) control over process of production; (iv) lack of social integration in a multicultural environment; (v) job tenure; (vi) inadequate qualifications; and (vii) mobility (Ramady, 2010; Shah, 2006). Given these situations and the need to gather sizeable job allotment of their national workforce to global workers and revise the imbalances of the labor market ratio where nationals found only ten percent of immersed nine million global workers [14]. This paper investigates the presumptions behind this acceptance, in an application to be aware better the burly ramifications of job localization policy to global workers and fundamentally evaluate the most qualified fresh saudization proposal pegged as "nitaqat" in the implementation procedure of the national manpower in Saudi Arabia.

\section{Saudi Development Plan and Job Localization Policy}

Saudi Arabia had directed significant change in numerous territories. Road were established, a cutting-edge instructive framework actualized, ameliorate health and medical services, agricultural business expanded and a few industrial facilities constructed. The fulfilled of such a financial change is when the advent for the first appearance of development plan (1970-1974) presented in 1970. A progression of campaign for monetary improvement proceeds with immaculate defined targets in the second (1975-1979) and third development plans (1980-1984). By 1985, with the majority of the advancement clinched alongside, the attention of government moved to the different qualities about investment sources (Ramady, 2010). Legislative activities for securing more prominent proficiency and security brought in the fourth development plan (1985-1989). In a critical review by Alanezi (2011) expresses that despite the fact that the Saudi administration examined about the required amount of nationals, the policy of job localization was not actualized until the fifth development plan arrived in 1990-1994 which emphasized the enormous deluge of global workers and growing number of unemployment among nationals. In a setting of five year plans, the national workers needs to take a closer reflection in any event to perceive the current policies of the legislature to facilitate the extreme weight of unemployment rate.

Amid past financial change in the kingdom, a restricted approach thwarted those change about job localization policy. For this situation, the sixth development plan (1995-1999) was formally started in 1994 with a point of making employments through the procedure of integration. The Ministry of Planning announced that creation of 34,000 new employments and integration of 659,000 Saudi nationals into the workforce for the substitution of 319,000 global workers. After the project delineated in 1995, the advancement of job localization policy was verified and reexamined in view of the national needs. The year 1995 additionally forced a clerical pronouncement that private organizations with more than 20 workforces ought to reduce the quantity of global workers at a yearly rate of five percent (Ibrahimkhan, 2007). This ministerial decree has been mirrored in the seventh development plan (2000-2004) which concentrated more on financial enhancement and a more prominent part of the private 
organization in the Saudi economy. The Saudi legislature pointed a business employment opportunities of 817,300 Saudis, 466,000 of which through Saudization and the remaining 328,700 through new employment creation, and twenty-five percent about employments were set in private organizations by 2004 (Al-Dosary \& Rahman, 2005). For this reason, the Saudi administration reserved 276 billion riyals for the fund of Human Resource Development (HRDF) and co-operative training scheme to build up further and create compelling current systems to agree to the requirements of the national labor market and to ensure the most astounding returns both in terms of quantity and quality. The asset will focus on the support, preparing, and livelihood of nationals in the private organizations. Alzalabani (2004) likewise conveyed that HRDF contributes seventy-five percent of the preparation expense and half of Saudi wage in the private organization for two years.

With those expanding amount of the labor market in the advancement procedure, it was common for the Kingdom to move towards demonstrative arrangement. The eighth development plan (2005-2009) takes the procedure of indicative planning to a more propelled level. The Saudi legislature now has unstoppable arrangements to expand the level of Saudi nationals. As indicated by the most recent study, the goal-oriented targets were held in the eighth development plan however focuses for administration areas were lessened from 30 percent to between 20 percent and 15 percent (Ministry of Planning, 2005). Aggregate registered occupation in the private sector added up to around 6.22 million workers, including 13.3 percent were local people (36 percent women). The job of nationals in private division constituted 10.7 percent in manufacturing and somewhere in the range of 17.4 percent in administration sectors (Ministry of Labor, 2008). Given this rate, the policy makers mix a few limitations on the employment procedure for Saudi nationals and incarcerate sure professions solely to them. It is expected that there will likewise be changes for Saudis to recover a scope of small businesses which have turned into the preserve of global workers.

The change around job localization policy was analyzed subsequently and endorsed targets were set in the ninth development plan (2010-2014) with the assigned spending plan of SAR1.4 trillion or proportional to USD385 billion for different improvement objectives, a record of 67 percent expansion in investing on the past plan (Talal, 2010). Under this financial plan, 50.6 percent is apportioned for human resource division including education sector and workforce skills improvement, 19 percent social development and health, 15.7 percent monetary asset advancement, 7.7 percent transportation and communication, and 7.0 percent metropolitan services and lodging activities. Jasim (2010) reiterated that it may be anticipated that those for every capita income might develop starting with SR46, 200 in 2009 to SR53, 200 by 2014. The allotment of administration is put aside to build up 117 new hospitals, 750 primary health care centers, 400 emergency centers, 25 new colleges of technology, 28 higher technical institutes and 50 industrial training institutes, in addition extending the limits of state funded colleges to 1.7 million students in primary, intermediate and secondary schools to 5.31 million students which would help with the objectives of financial enhancement (Saudi Embassy, 2010). As indicated by the Global Innovation Index of 2012 in France, the ninth development plan perceived advanced education as a standout amongst the most imperative phases of the development towards an information-based 
economy (Al-Sultan \& Alzaharnah, 2012). These included beginning to actualize the first five year plan of the Science and Technology National Policy, receiving the national ICT arrangement, the national industrial technique, and the system and arrangement for talented, inventiveness and advancement. The outcome has been an incredible increment in the beneficial employment of Saudi locals and a consistent redesigning of ability levels and occupational accomplishments of the Saudi workforce (Ibrahimkhan, 2007).

\section{Nitaqat Program as A Quota-based System}

In June 2011, the Saudi administration uncovered another system known as "Nitaqat program". Nitaqat is an Arabic term which means "ranges" or "limits". This immediate intercession activity plans is to convey fast effects and provide Saudi nationals an exceptional stand in the labor market. In looking into the report, organizations will be assessed through the rate of employments by local people and evaluate depends on their execution into the workplace (Dudley, 2012). The reason of this plan is to offer inventive and practical arrangements and to abate glitches and issues of nationals and global workers. The point of convergence of this plan is the financial development of unemployment, however there are likewise basic social and political interests. The "Nitaqat program" is an exceptional system planned by the Ministry of Labor to ensure the enthusiasm of nationals and an effort to support the services of global workers. This system was acquainted with improvement to the adequacy of job localization policy as to the level of unemployment in the Kingdom. Figure 1 and 2 delineates the unemployment level of Saudi Arabia in 2012.

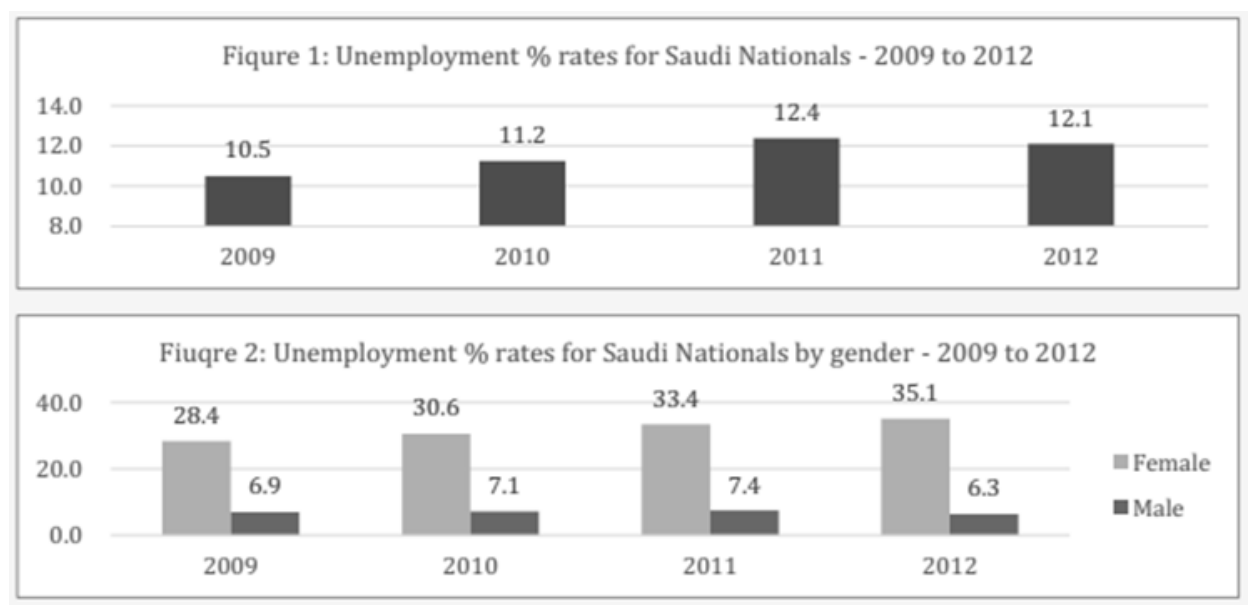

Figure $1 \&$ 2. Unemployment rate

Source: Department of statistics and information—manpower research bulletin.

In a late report, Central Department of Statistics and Information (2012) distributed its assessments of unemployment rate among Saudis in 2012 which remained at 12.1 percent and expansion of 1.6 percent since 2009. Figure 1 and 2 represented that while aggregate unemployment is 12.1 percent which interprets on 602,853 Saudi nationals who are no jobs, 
female unemployment expanded from 28 percent in 2009 to 35 percent in 2012. The unemployment rate for Saudi women with a professional education remained at 73.3 percent. The 25-29 age groups have the most astounding unemployment rate at 37.6 percent. In any case, the unemployment rate for Saudi males has marginally diminished from 6.9 percent from 2009 to 6.3 percent in 2012 (Majeed, 2013). Nonetheless even with such unemployment figures for Saudi nationals, a considerable number of occupations in the Kingdom are as yet being filled by global workers (Gallarotti \& Al-Filali, 2012; Gause \& Jones, 2012; Lippman, 2012). Additionally, in 2009, it was evaluated that the workforce of global workers remains at 80 percent and roughly 524 billion or equivalent to USD139 billion remittances left Saudi Arabia particularly on a real significant labor exporting nations, for example, Egypt, Malaysia, Bangladesh, Pakistan, India, Indonesia and the Philippines.

It was expressed that "Nitaqat" program is an exercise in careful control between contributing to the Saudi economy and decreasing the quantity of work visas for global workers to contract Saudi citizenries (Harrison-Mirfield, 2011). The Ministry of Labor reported that more than 300,000 employments had been made by the "Nitaqat" program to date, which set a limit to the exchange in work visas (Al-Sulami, 2011). To do this plan and make standards reasonable and likewise useful, the Ministry of Labor is concocting 41 categories of its employment segments. It additionally characterizes organizations under five classifications as indicated by the quantity of their workforce. The "Nitaqat" program does not set constantly on elements clinched in one spot. The elements are further positioned into 164 clusters (41 categories $\mathrm{x} 4$ zones). Each cluster will arrange organizations into four zones or bands as stated by agreeability with the saudization necessities. It is also a shading-coded framework that remunerates organizations for implementing good conduct technique and rebuffs individuals or organizations that neglect to employ adequate nationals. Under this scheme, organizations are described as premium with the colored green, yellow and red as per their rate (Gavin, 2012). The rate that will apply relies on upon the (i) activity of the organization and (ii) the business size as appeared in Table 1.

Table 1. The Saudization percentage

\begin{tabular}{|l|l|l|l|l|}
\hline Business Size & Red & Yellow & Green & Premium \\
\hline Small (10-49) & $0-4 \%$ & $5-9 \%$ & $10-39 \%$ & $\geq 40 \%$ \\
\hline Medium (50-499) & $0-5 \%$ & $6-11 \%$ & $12-39 \%$ & $\geq 40 \%$ \\
\hline Large (500-2,999) & $0-6 \%$ & $7-11 \%$ & $12-39 \%$ & $\geq 40 \%$ \\
\hline Huge (3,000+) & $0-6 \%$ & $7-11 \%$ & $12-39 \%$ & $\geq 40 \%$ \\
\hline
\end{tabular}

Source: DLA Piper, newsletter-Middle East June (2012).

As demarcated above, there are four classifications over which organizations will get a spate advantages and impetuses, or be liable to restrictions of services and face subsequent measures. The organizations with Premium and Green categories or who have remarkable track records in such manner will get particular rewards that include: capacity to employ 
global workers from non-satisfactory "yellow" and "red” categories even without businesses agreement, and the ability to exchange of visas and change of individual's position, yet the service would be accessible just once at regular intervals. Further, organizations in "green" category will pick up the upside of a state-of-the-art visa endorsement process within ten days as the service moves toward distributing visa issuance (MENAFN, 2011). However, organizations in "green" category are delighted to utilize Saudis and register them with the General Organization for Social Insurance. Yellow category is the organizations that are in consistence with saudization however liable to numerous confinements. A research by Jabarti (2011) affirmed that the organizations will be permitted to renew their labor licenses provided they have not finished over six years in the kingdom, and are given an extension of nine months to amend and advance their status. Red category is the organizations that are denied of essential service of ministry, for example, (i) apply for new; (ii) replacement; (iii) or seasonal visa; (iv) change their foreign workers' professions; and (v) document application for opening new enterprises whether they are the branches or entities. Both yellow and red organizations will fail to regulate over their global workers who look for an employment at organizations in green and premium categories. It will likewise be banned from renewing work visas of their whole global workers. Organizations with less than 10 years are presently exempted under the "Nitaqat" program yet should in any case utilize no less than one Saudi national (DLA Piper, 2012).

In light of recent and perhaps approaching transformation, the bureaucracy begun to implement an additional exhilarated strategy to guarantee that more citizenry obtain plausible businesses as well as employment opportunities in the Kingdom in addition to bring considerably better earnings and more positive aspects as compared to global workers (Dudley, 2012; CIA, 2011). A few businesses may also be supplying distinctive scholarships and grants as well as internships wherein they just do not simply deliver practitioner-recommended training programs yet at training they are given a salary and benefits and then injected into a position of management within the organization after generative achievement of the training program. The Ministry of Labor also offers exorbitant approach by digitizing the entire practice and afterwards constructing a solver strategy to assist organizations acclimatizing their initiatives in this particular up-to-the-minute process (Sadi, 2013). The government's intention is to always flourish in delivering several million employment potentials for Saudi nationals by 2014, or 92 percent of every different work opportunities prepared as initiate in present development plan (Sfakianakis, 2011).

\section{Key Initiatives to Support Job Localization Policy and Nitaqat Program}

The most valuable objective of Saudi Ministry is that individuals will be the first option for businesses and career hunters will provide the necessary skills by the business industry managers. On top of that, the Ministry of Labor performs currently to backup Nitaqat program by designing the staffing instruments, delivering a well-designed training and consulting services and having technical and financial aid for both of managers and career hunters, to be able to augment the essence of saudization. Number one is Hafez, is an approach offering financial aid to roughly 500,000 jobless individuals at some stage in their promising career path. It is also considered as unemployment benefits national program that 
subsidies a monthly allowance of SR 2000 (\$533) to Saudi residents (McDowall, 2012). As demonstrated by Labor Ministry, an effort of searching employment must initially settle all responsibilities and obtain an absolute no consequences for a certain time of two months before financial assistance commences. Nevertheless, the moment the beneficiaries did not succeed to abide by the program regulations, for instance, showing up at employment interviews and training sessions there might be plausible to suffer a loss of their stipends or possibly might determine by future financial consequences as indicated in table 2 . While at the same time, the Saudi government has introduced the Liqaat program. The program to be adopted by a qualified enterprise is a collaborative knowledge and interest between the Ministry of Labor and the Human Resources Development Fund. This program intends to assist career hunters throughout career exposure across the nation and organize the employment interviews between managers and career hunters. Qualifications along with relevant dossiers were examined and nominated for employment interviews.

Table 2. Subjected financial penalties from the program

\begin{tabular}{|l|l|l|}
\hline Failed obligation & Penalty & Termination \\
\hline Failing to complete periodic sign on (PSO) & 200 SAR & After 6 occurrences \\
\hline Not completing an assigned training & 200 SAR & After 4 occurrences \\
\hline Not attending an interview & 200 SAR & After 4 occurrences \\
\hline Rejecting a suitable job offer & --- & After 3 occurrences \\
\hline
\end{tabular}

Source: www.taqat.sa (https://www.taqat.sa/en/web/guest/hafiz-searching-for-employment).

In an effort to strengthen the performance of the Nitaqat program, the Saudi ministry is focusing on building an extensive repository that equipped with significant variables in the supply and demand for labor. This labor market observatory benefits the state organizations to observe and comprehend the market statistics, and also performance contributes in supporting the check-and-balance procedure. They are designing staffing instruments such as "recruiting and leasing employees". The intention of this effort ought to deliver an effective way of workforce employment for organizations in an open-ended method. At this current discourse of technological innovation, the Saudi ministry introduced a "virtual career fair" by going online with protected engines for job opportunities which could be now offered to a nearby aspirant having a broadband internet access. Further, the authorities escalate the alliances between both government-owned and private-owned organizations in the area of technical and vocational education and training as well as assistance in SME management training and recruitment plans (Alshanbri et al., 2015). Lastly, the Saudi government offers to launch a salary security system designed to electronically scrutinize the subsidy of salaries to both national and global workers and consequently guarantee that general contractors accomplish their responsibilities. The program would also exclude workforce from performing a variety of works simultaneously. It will probably be applied in a sequence approach, starting with sizable organizations and moderately expanding to small-scale businesses (Saudi Hollandi Bank, 2012). 


\section{Impact of Policy and Program on Saudi Arabian Economy}

The research alludes that program would certainly provide crucial influence on trades which include agriculture and wholesale \& retail trade, whereas trades particularly insurance would be soundly less affected. This study ultimately focused to the agricultural sector. Facts and figures from Saudi Arabian Monetary Authority signify that this sector regarded for 7 percent of entire private employment and received a saudization percentage of just 1.8 percent previously. This requires to be witnessed against the boundaries defined by Nitaqat program. As outlined by Al-Abdullah's research (2011), the Nitaqat program shall adversely affect the agricultural sector because 95 percent of the rural areas with farms are being branded in the red category. The agricultural sector is not eye-catching to the nationals as the work demands lengthy time under the sun and separate from the metropolitan areas. Venture capitalists are confused about who is going to sustain and preserve the colossal financial investment that was infused into retrieval of uncounted square meters over the past years. Entrepreneurs are anxious about the major disruption when they required employing Saudi workforce with least pay check of SR 3000. It signifies that entrepreneurs might need to discharge several global workers that handle multiple jobs simultaneously for the salary of one position. They are also indecisive if or not Saudi nationals may settle for dealing with the equal arrangements. Executives of various establishments such as local translation office, stationery stores, marketing agencies and the rest find themselves in a difficulty. And even governance on how to influence Saudi nationals to do business for them. It is revealed that Saudi Arabia's motivation to force organizations to seek the services of more nationals could decrease the restoration of the independent sector. This tends to tremble already the assurance of vulnerable overseas market players in the economic system of the nation.

The next sector described in this research was wholesale and retail trade. Monetary agency of Saudi Arabia roughly calculates that sector which balances out 21.5 percent of entire private employment had a saudization percentage of 12.6 percent in the past years. As per the Nitaqat program, businesses from this sector acquiring no less than 10-49 workforces are required to grasp a percentage of at least 10 percent to be considered under the Green and Excellent categories. Likewise, for larger framework of wholesale and retail stores hiring beyond 50 workforces appear to be problematic (Saudi Hollandi Bank, 2012). Nevertheless, according to management outline of McKinsey Global Institute, Saudi Arabia's retail sector can potentially prosper considering that web-based retail and modernized set-ups substitute conventional baqala stores in the community. In general, it has been calculated that wholesale and retail trade have an opportunity to recruit on the average of 800,000 extra citizenries over the subsequent years. Retail trade seems to be increasing quickly with 12 percent yearly rate over the past decade, driven by the growth in household earnings. Even though human resources at this point generally contains low-income for global workers, the quantity of individual active in this sector is doubled up between 2010 and 2014. It is often a section wherein female as an example have discovered an occupation which jumped from 10,000 in 2010 to 120,000 in 2014. This exhibits a motivation by the Saudi authority to stimulate saudization and feminization of wholesale and retail groups providing to females, such as cosmetic or lingerie sections. Tailoring the latest retail set-ups, migrating fast web-based network, and providing 
the most suitable procedures in merchandizing, as well as supply-chain effectiveness which include a rise of computerization in warehousing would drastically increase production and advancement (McKinsey Global Institute, 2015).

It is interesting to note that building and construction sectors are also evaluated in this research. As seeing the leading member of the GCC endowed with enormous hydrocarbon reserves, it is not difficult to understand why Saudi Arabia is frequently recommended as the next dominant construction market in the community. Irrespective of addressing difficulties and intertwined drawbacks, the government's decision to drive advanced with an aggressive growth plan has signaled a myriad of building and construction businesses to the nation's prospective. For instance, the building and construction organizations with activities scheduled under government's 10th Development Plan including investments are worth \$258.2bn in real estate; \$151.5bn in petrochemicals; and \$126.7bn in electricity, gas and water (Oxford Business Group, 2015). In reality, for the short term, expenses for contractors as well as the bigger construction sectors are refining due to the decline in petroleum values. Then again, overseas corporations are getting determined in the market because of recent approaches to help streamlined the procedures of market access for international construction organizations. The advent of an upgraded law is getting rid of hindrances for construction across the nation is anticipated to include in the momentum of government's infrastructure attention. Authorities indicate that extensive investments from non-public sector should translate into persistent demand for construction. They should become more cost-efficient, embracing contemporary innovations and strengthening management operation in order to carry out assignments promptly and on available resources. At present, approximately 9 out of 10 individuals in the sectors are global workers. If the present government stigma of employed in building and construction might perhaps be reduce, the sector could turned into a valuable driver of country's future employment bond.

And then, transport, storage and communications sector is also recognize for exploration in this research. A huge component of the wholesale \& retail trade provides an immediate effect on the transport and storage sections. An exceptional viewpoint for wholesale and retail trade indicates effectively for transport and storage. The transport section is often beefed up by the total economic activities simply because it produces interest on organization and business and leisure travelling (Al Rajhi Capital, 2015). As outlined by monetary agency in the Kingdom, the transport, storage and communications sector obtained a Saudization percentage of 15.3 percent in 2010. The sector augments approximately 10.5 percent from the full employment of existing non-public sector in the Kingdom. The nitaqat program summed up the transport sector into three categories: (i) transport of commuters and merchandizes (outside cities), (ii) ground transportation of commuters (within city), and (iii) road transport of merchandizes (within city). Comparing the mediocre of Saudization figure from SAMA for these sectors, the research considers that program may not obtain more influence on the sectors. Alternatively, transport businesses argue that it's difficult to find and employ local individuals and meet the nitaqat objectives because populace is hesitant to occupy this kind of job opportunities.

Pursuing this further, the researches recognize the importance of insurance sector as being an 
additional variable which remarkably less hampered. The insurance sector ensured a Saudization percentage of 50 percent in 2010 with over 3,500 local individuals employed to work (Saudi Arabian Monetary Agency, 2011). The program requires organizations in the insurance and business service sector with more than 500 workforces to have a Saudization percentage with a minimum of 20 percent to be categorized under higher categories. Which means the insurance sector might not be wedged plenty as the mediocre of Saudization percentage is definitely above this objective. The synopsis of this factor is that insurance sector has been taking benefits from the government economic and business policies to expand the protection plan. Medical and health care insurance leads the insurance sector. The significance of health care insurance for global workers has delivered an enhancement to the sector. Likewise, the Saudi authority's aspiration to implement and improve the needed of health care insurance to their residents guarantees an organizational assistance to the insurance and business service sector (Al Rajhi Capital, 2015).

\section{Methodology of the Study}

Important information for this research was extracted from qualitative method of inquiry with the executive managers which concentrate on the manifestations of human resource dogmas and presently applied with the multiple organizations. It is also utilized supplementary resources which taken from appropriate scientific studies, legitimate publications and leading broadsheets, and published remarkable contents and figures from Ministry of Labor. The functionality of using proposed material for investigation is becoming more comprehensive because of its predefined degree of authenticity and consistency which does not have to be reassessed. It similarly delivers persistent preference for experts and academic scholars to generate their research investigation more comprehensive in order to deliver their findings effectively in a limited time and valuable assets (Andrews et al., 2012; Johnston, 2014). Also, the localization limitations from the HR executive manager's perspectives along with the repercussions of Nitaqat program on the existing international workforce in the societies. The fundamental solution of the program from their standpoint is to augment the performance of organization by supplanting the existing non-Saudi workers with native individuals. The outcome that named in the subsequent part is merely relevant to the challenges and constraints of Nitaqat program from HR managers’ outlook in non-government entities.

\section{Initial Results}

Among the localization limitations in the Kingdom is the prerequisite of citizenry that could be associated with their educational systems. This challenge was brought up during the meeting with human resource executives in both yellow and green zone organizations. The outlook of educational system in the Kingdom nevertheless is essentials for serious provision from Saudi authority to improve the education distribution and significance. Also to accomplish of competencies and assertiveness they required to blend with the aspiration of the country's visualizations especially in both practical and professional abilities. Next challenge is Job Type which is also correlated to the educational systems. Retaining and boosting an extensive foundation of technical and competent workforce is debatable as nationals seem to be more focused to managerial position in the workplace. Additionally, 
several youngsters have been raised in luxurious lifestyle, witnessing their parents and relatives receiving lucrative salary as well as having a higher status (Bell, 2005). This viewpoint is profoundly originated to the details that all the descendants of common ancestor and the government authority safeguard and sustain those who avoid the socially displeasing career opportunities (Yadav, 2005). For that reason, most blue-collar jobs that involve physical task appeared unpleasant and unethical for them.

Table 3. Average monthly wages: Comparison of Saudi Nationals and Non-Saudi (in SAR)

\begin{tabular}{|l|l|l|l|}
\hline Main Occupation & Saudi Nationals & Non-Saudis & \% Non-Saudi to Saudi \\
\hline Administrative & 14858 & 13160 & $88 \%$ \\
\hline Professional, technical and related work & 9394 & 4758 & $51 \%$ \\
\hline Clerical & 6212 & 3816 & $61 \%$ \\
\hline Sales & 4537 & 2127 & $47 \%$ \\
\hline $\begin{array}{l}\text { Production, transport, equipment } \\
\text { operator }\end{array}$ & 5420 & 1519 & $28 \%$ \\
\hline Services & 3975 & 1261 & $30 \%$ \\
\hline $\begin{array}{l}\text { Agriculture, animal husbandry and } \\
\text { fisherman }\end{array}$ & 3191 & 1000 & $31 \%$ \\
\hline Not reported & 3963 & 2512 & $63 \%$ \\
\hline General average & 7034 & 2354 & $33 \%$ \\
\hline
\end{tabular}

Source: Ministry of Labor (2013) (www.mol.gov.sa/docs/107.htm).

It is interesting to note that earnings are further viewed as one of the limitations for job localization program. In table 3, it signifies that Saudi remunerations in each occupation are doubled compare to global workers. Due to the average monthly wages and compensation among nationals, non-public sectors have become increasingly dependent on global workers which are estimated to number about 9 million (Arab News, 2013). Moreover, human resource management executives as well pointed out that unessential workforce and hours of duty are observed as deterrents to the job localization program in the Kingdom. These constraints attributed to the social lifestyle of individuals are required for in-depth investigation to ascertain the potential of nationals in working at night or irregular shifts.

Through the secondary data there are several diverse topics and parts were highlighted in an effort to move forward the business into advance and complex level. A great number of solutions as well as creative concepts were ascended. However, the significant concerns were most of the approaches discovered that different organizations are controlling or influencing unscrupulously the Nitaqat program as an example by listing immediate family and close colleagues as a genuine workforce with social security body in the program through fictitious saudization. This technique is organized by organizations in green category to thwart Nitaqat's fees and penalties. In addition to that, is to reach the marginal percentage of saudization quota and abstain from perilous categories (Koyame-Marsh, 2016). For this 
reason, Ministry of Labor found out and temporarily cancelled 14 commercial organizations for performing fictitious saudization. Hence, they introduced an in-depth plan to combat the rigmarole of false employment. They prepared preliminary standards for top executives who involved in fictitious Saudization, by facing substantial comeuppance, cutting of all benefits from the HRDF, no recruiting of first-hand workers and a mulct of up to 10 million riyals (Naffee, 2015). A great way to handle Nitaqat program is by integration with existing organizations and includes individuals who are employed in another organization in the same system. More importantly, employing female worker is counted as two male workers. Research indicates that it is a way for domestic organizations to motivate and absorb as much as nationals neither male nor female parties (Alshanbri, 2015).

\section{Conclusion}

Modification of the financial-base continues to be a significant agenda for Saudi Arabia's commercial and sociable progress. It is by far executed in a substantial phase as part of continual process for sustainable innovation. Undoubtedly one of the main points of development is to support and sustain knowledge management of Saudi human resources. However, previous years seen the penetration of multinational specialists in Saudi Arabia attributable to their abilities and competencies. Thereupon, Saudi government executed "job localization policy" and "nitaqat” programme to elevate recruitment among local citizenries and scale back the quantity of global workers. They believe that this strategy definitely will resolve the predicament on the shortage of knowledge management that contributed to extreme unemployment rates.

To address increased unemployment percentage, the bureaucracy with dynamic collaborative involvement of non-public organizations really should generate Saudi nationals an increased place in the labor market as well as integration of boundaries on the recruitment of multinational workers, whilst job localization policy may emerge as appropriate for the economy's multiplicity, competitiveness and improvement possibilities. In the perspective of development plan, this strategy will provide distinctive and controllable approaches to alleviate the issues and predicaments of Saudi nationals and global workers in the course of percentage of work opportunities populated by locals and ranked as outlined by their effectiveness. That was deemed as a priority subject of the Saudi legislature, besides education and training continued to be the sections of distress. For these reasons, the Saudi government must cultivate the individuals and private organizations to perform an additional excellent activity in a consistent and versatile financial position, while simultaneously making an attempt to disembark the reflections and consequences of the sound of disturbed and underemployed nationals around guaranteed quota access.

\section{References}

Alanezi, A. (2011). The impact of human resources practices on the success of job localization policy in Saudi financial industry. In proceedings of Brunel Business School Doctoral Symposium 28th \& 29th March. Brunel University London, Great Britain.

Alanezi, A. (2012). Workforce localization policies in Saudi Arabia: the determinants of 
successful implementation in multi-national enterprises. In proceedings of management, knowledge and learning international conference 2012. Brunel University London, Great Britain.

Al-Abdullah, M. (2011). Nitaqat gets 95 percent of farmers in Red Zone. [Online] Available: http://www.sauress.com/en/saudigazette/105132

Al-Asfour, A., \& Khan, S. A. (2014). Workforce localization in the kingdom of Saudi Arabia: Issues and Challenges. Human Resource Development International, 17(2), 243-253. https://doi.org/10.1080/13678868.2013.836783

Al-Barjas, B. (2016). Unemployment facts and figures. [Online] Available: http://saudigazette.com.sa/opinion/local-viewpoint/unemployment-facts-figures/

Al-Dosary, A. S., \& Rahman, S. M. (2005). Saudization (Localization)-A critical review. $\begin{array}{llll}\text { Human resource development international, 8(4), } & \text { 495-502. }\end{array}$ https://doi.org/10.1080/13678860500289534

Al-Dosary, A. S., \& Nahiduzzaman, K. M. (2010). A futuristic discourse of higher education system linkages with the labor markets in the kingdom of Saudi Arabia. International journal of Arab culture, management and sustainable development, 1(4), 326-339.

Al Rajhi Capital. (2015). Saudi Arabian economy: Mid-year review. Economic Research, 1-13. [Online] Available: http://www.marketstoday.net/includes/download.php?file=rr_08062015172821.pdf\&lang=en $\& s=310 \& m=$ research

Alshanbri, N., Khalfan, M., \& Maqsood, T. (2015). Localization barriers and the case of Nitaqat program in Saudi Arabia. Journal of Economics, Business and Management, 3(9), 898-903.

Alshanbri, N. M. (2015). Investigating the role of Knowledge Management and Human Resources Management in assisting the Employee Replacement Process: The Case of Saudi Arabia's New Localisation Program "Nitaqat". Doctoral Thesis, RMIT University, Melbourne, Australia.

Al-Sulami, M. (2011). Nitaqat to end trade in work visas: Fakeih. McClatchy-Tribune Business News, Washington, United States.

Al-Sultan, K. S., \& Alzaharnah, I. T. (2012). Academia-Industry Innovation Linkages in the Case of Saudi Arabia: Developing a University-Industry Triple-Helix Framework to Promote Research and Development Collaboration. In S. Dutta (Ed.), The Global Innovation Index 2012: Stronger Innovation Linkages for Global Growth (pp. 89-95). France: INSEAD.

Altamimi, A. M. (2014). Challenges Experienced by Saudi Female Students Transitioning Through Canadian Pre-academic ESL. Masteral Thesis, Mount Saint Vincent University, Halifax, Nova Scotia, Canada.

Alzalabani, A. H. (2004). Industrial relations and labor market in Saudi Arabia, paper 
presented at the conference of the International Industrial Relations Association (IIRA), Seoul, Korea, June 2004.

Andrews, L., Higgins, A., Andrews, M. W., \& Lalor, J. G. (2012). Classic grounded theory to analyse secondary data: Reality and reflections. The Grounded Theory Review: An International Journal, 11(1), 12-26. [Online] Available: http://groundedtheoryreview.com/2012/06/01/classic-grounded-theory-to-analyse-secondarydata-reality-and-reflections/

Arab News. (2013). New plan to nab illegals revealed. [Online] Available: http://www.arabnews.com/news/448234

Bell, B. (2005). Saudi Arabia's job market rethink. [Online] Available: http://news.bbc.co.uk/2/hi/middle_east/4137898.stm

CIA. (2009). World factbook: Saudi Arabia. [Online] Available: http://www.cia.gov.library/publications/the-world-factbook/geos/sa.html

CIA. (2011). World factbook: Saudi Arabia. [Online] Available: http://www.cia.gov.library/publications/the-world-factbook/geos/sa.html

Central Department of Statistics and Information. (2012). Manpower research bulletins. [Online] Available: http://www.cdsi.gov.sa/english/index.php?option=com_docman\&task=cat_view\&gid=85\&Ite $\operatorname{mid}=162$

Coates-Ulrichsen, K. (2011). Insecure gulf the end of certainty and the transition the post-oil era. New York: Columbia University Press.

De Bel-Air, F. (2015). The Socio-Political Background and Stakes of "Saudizing" the Workforce in Saudi Arabia: the Nitaqat Policy. Gulf Labour Markets and Migration, Explanatory Note No. 3/2015, pp. 3-25.

DLA Piper. (2012). Be aware-focus on Kingdom of Saudi Arabia. Middle East Newsletter, 1-6. [Online] Available: https://www.dlapiper.com/en/saudiarabia/globalreach/global/middle-east/

Dudley, D. (2012). Expanding Nitaqat's success. MEED: Middle East Economic Digest, 56(41), 38-39. [Online] Available: www.meed.com

Elhadj, E. (2010). Saudi Arabia's agricultural project: from dust to dust. Middle east review of international affairs, 12(2), 134-145. [Online] Available: http://www.rubincenter.org/meria/2008/06/elhadj.pdf

Gallarotti, G. M., \& Al-Filali, I. Y. (2012). Saudi Arabia and the Use of Soft Power. Unpublished paper, Wesleyan University. June.

Gause, F. G., \& Jones, T. C. (2012). Saudi Arabia in the New Middle East. Presentation. Council on Foreign Relations, January 26. [Online] Available: http://www.cfr.org/saudi-arabia/saudi-arabia-new-middle-east/p27205 
Gavin, J. (2012). Moving forward with nationalization. MEED: Middle East Economic Digest, 56(27), 38-41. [Online] Available: www.meed.com

Hammer, M., Leonard, D., \& Davenport, T. (2004). Why don't we know more about knowledge? MIT Sloan management review, 45(40), 14-18. [Online] Available: www.sloanreview.mit.edu

Harrison-Mirfield, S. (2011). An overview of Saudi nitaqat (Saudization). KPMG International Cooperative, 28 November.

Hertog, S. (2012). A comparative assessment of labor market nationalization policies in the GCC. In H. Steffen (Ed.), National employment, migration and education in the GCC. The Gulf Region: economic development and diversification, 4. Berlin, Germany: Gerlach Press.

Ibrahimkhan, M. W. (2007). Income as possible factor in the employment of Saudi in private and public sector organizations: a human capital theory approach. Unpublished dissertation. Ball State University.

Jabarti, S. (2011). Nitaqat is fair to all: Fakeih. Mc-Clatchy-Tribune Business News. Last updated: 2011-08-13. [Online] Available: http//search.proquest.com/docview/883245601 ?accountid=136258

Jasim, A. (2010). Saudi development plan looks to resources. Special to Gulf News. [Online] Available:

http://gulfnews.com/business/opinion/saudi-development-plan-looks-to-resources-1.668246

Johnston, M. P. (2014). Secondary data analysis: A method of which the time has come. Qualitative and Quantitative Methods in Libraries, 3, 619-626. [Online] Available: http://www.qqml.net/papers/September_2014_Issue/336QQML_Journal_2014_Johnston_Sep t_619-626.pdf

Koyame-Marsh, R. O. (2016). Saudization and Nitaqat programs: Overview and performance. In proceedings of Annual South Africa Business Research Conference 11-12 January 2016, Taj Hotel, Cape Town, South Africa.

Lippman, T. W. (2012). Saudi Arabia on the Edge: The Uncertain Future of an American Ally. Washington, D.C.: Potomac Books.

Majeed, J. (2013). Why Nitaqat is needed? People excellence consultancy, 1-2. [Online] Available: http://www.pesync.com/uploads/3/2/1/8/3218394/why_nitaqat_is_needed.pdf

McDowall, A. (2012). More than 1 million Saudis on unemployment benefit. [Online] Available:

http://www.reuters.com/article/us-saudi-unemployment-subsidy-idUSBRE82R0L320120328

McKinsey Global Institute. (2015). Saudi Arabia beyond oil: The investment and productivity transformation. [Online] Available: http://www.mckinsey.com/global-themes/employment-and-growth/moving-saudi-arabias-eco nomy-beyond-oil 
MENAFN-Middle East and North Africa, Financial Network. (2011). New extreme Saudization plan. [Online] Available: http://www.menafn.com/menafn/1093421544/New-extreme-Saudization-plan

Ministry of Labor. (2008). Government of Saudi Arabia, Riyadh. [Online] Available: http://jeg.org.sa/data/modules/contents/uploads/infopdf/1824.pdf

Ministry of Planning. (2005). Kingdom of Saudi Arabia, 8th Development Plan 1421-1425 A.H. 2005-2009. [Online] Available: http://www.mep.gov.sa/

Naffee, I. (2015). Heavy Penalties for Hiring Female Ghost Workers, Arab News, 21 September 2014, Jeddah. [Online] Available: www.arabnews.com/Saudi-arabia/news/633201

Oxford Business Group. (2015). The report: Saudi Arabia 2015. [Online] Available: http://www.oxfordbusinessgroup.com/saudi-arabia-2015

Ramady, M. A. (2010). The Saudi Economy: Policies, Achievements, and Challenges. New York: Springer. https://doi.org/10.1007/978-1-4419-5987-4

Randeree, K. (2009). Strategy, policy, and practice in the nationalization of human capital: project emiratization. Research and practice in human resource management, 17(1), 71-91. [Online] Available: https://rphrm.curtin.edu.au/2009/issue1/emiratisation.html

Randeree, K. (2012). Workforce nationalization in the gulf cooperation council states. Occasional paper no. 9. Center for International and Regional Studies-Georgetown University School of Foreign Service in Qatar. [Online] Available: https://repository.library.georgetown.edu/bitstream/handle/10822/558218/CIRSOccasionalPa per9KasimRanderee2012.pdf?sequence $=5$

Sadi, M. A. (2013). The implementation process of nationalization of workforce in Saudi Arabian private sector: a review of "nitaqat scheme”. American journal of business and management, 2(1), 37-45. https://doi.org/10.11634/216796061302294

Saudi Arabian Monetary Agency (SAMA). (2011). Forty Seventh Annual Report, Riyadh. [Online]

Available: www.sama.gov.sa/.../EconomicReports/AnnualReport/6500_R_Annual_En_47_2011...

Saudi Embassy. (2010). Ninth development plan (2010-2014) approved. [Online] Available: http://www.saudiembassy.net/latest_news/news08091005.aspx

Saudi Hollandi Bank. (2012). Labor and the nitaqat program: Effect on Saudi economy. [Online] Available: https://www.alawwalinvest.com/content/laborandthenitaqatprogram.pdf

Sfakianakis, J. (2011). Saudi Arabia Economics-June 2011, Banque Saudi Fransi. Saudi British Relations. [Online] Available: www.saudibrit.com/2011/06/21/saudi-arabia-economics-june-2011-bsf-2/+\&cd=1\&hl=en\&ct $=\mathrm{clnk} \& g \mathrm{l}=\mathrm{sa}$

Shah, N. M. (2006). Restrictive labor immigration policies in the oil-rich gulf: Effectiveness and implications for sending Asian countries. United Nations Expert Group Meeting on 
International Migration and Development in the Arab Region.

Spiess, A. (2010). Demographic transitions and imbalances in the GCC: security risks, constraints and policy challenges, conference policy paper presented at the 2010 Exeter gulf studies, conference: the 21st century gulf: the challenge of identity, June 30-July 3.

Talal, A. (2010). Saudi Arabia invests $\$ 385$ billion in development projects. Global Arab Network.

Available:

http://www.english.globalarabnetwork.com/201008116877/Economics/saudi-arabia-invests-3 85-billion-in-development-projects.html.

Taqat. (n. d.). Hafiz: Searching for employment. [Online] Available: https://www.taqat.sa/en/web/guest/hafiz-searching-for-employment

Torofdar, Y. (2011). Human resource management in Saudi Arabia: a closer look at saudization. In proceedings of 14th international business research conference 2011. Dubai, UAE. p. 26.

Winckler, O. (2010). Labor migration to the GCC states: patterns, scale, and policies. Migration and the gulf, viewpoints special ed., middle east institute, Washington, DC.

Yadav, V. (2005). Arab culture and poverty. [Online] Available: http://www.aucegypt.edu/faculty/vyadav/ipe/2005/05/arab-culture-and-poverty.html

\section{Copyright Disclaimer}

Copyright for this article is retained by the author(s), with first publication rights granted to the journal.

This is an open-access article distributed under the terms and conditions of the Creative Commons Attribution license (http://creativecommons.org/licenses/by/3.0/). 